\title{
Simultaneous Typhoid and dengue hemorrhagic fever a case report
}

\author{
R.H.H. Nelwan
}

\begin{abstract}
Abstrak
Seorang wanita Indonesia, 38 tahun, masuk rumah sakit dengan riwayat 5 hari demam, sakit kepala, nyeri abdomen dan diare ringan. Pemeriksaan fisik hanya mendapatkan nyeri pada palpasi daerah epigastrika. Uji laboratorium menunjukkan trombositopenia, lekopenia, pergeseran ke kiri dan peningkatan tajam nilai $\mathrm{C}$-reactive protein. Ia muntah dan mual setelah masuk rumah sakit. Ia tidak demam pada pagi ia masuk tetapi menjadi demam setelah itu. Ia diberi IVFD Ringer lactate, metoklopramid untuk mengatasi muntahnya, dan antipiretik. Selama 3 hari pertama di rumah sakit, demamnya naik setiap hari hingga mencapai $40^{\circ} \mathrm{C}$ pada hari ketiga. Hasil uji dengue blot positif untuk $\lg G$ dan IgM menunjukkan infeksi sekunder dengue. Meskipun bukti klinis dan laboratorium demam dengue akut telah ada, pola peningkatan bertahap suhu hariannya (step ladder) setelah demam terus-menerus selama 5 hari di rumahnya (yang dapat disebabkan oleh virus dengue), menunjukkan kemungkinan adanya infeksi Salmonella typhi secara bersamaan amat besar Kepada pasien diberikan terapi fleroksasin $400 \mathrm{mg}$ setiap hari intravena dan demam menurun dalam 3 hari. Dua hari kemudian, pasien meninggalkan rumah sakit. Biakan darahnya menghasilkan Salmonella typhi sensitif terhadap fluorokuinolon, menjelaskan cepatnya respons pengobatan. Fluorokuinolon lebih disukai karena tidak ada efek penekanan sumsum tulang, yang penting untuk pemulihan hematopoetik setelah infeksi dengue. Tidak dijumpai interaksi penyakit yang berat atau perpanjangan masa tinggal di rumah sakit pada kasus infeksi ganda ini. Dengan menggunakan jenis intervensi yang tepat, dapat diharapkan hasil terapi yang memuaskan.
\end{abstract}

\begin{abstract}
A 38 years old Indonesian female was admitted with a 5 day history of fever, headache, abdominal pain and slight diarrhea. Her physical examination only noted pain on palpation of the epigastric area. The laboratory test showed thrombocytopenia, leucopenia, a shift to the left and highly increased C-reactive protein values. She vomited and felt nauseated after admission. She was afebrile on the morning of admission but developed fever later during the day. She was put on a IVFD with Ringer lactate and was also given metoclopramide against vomiting and an antipyretic. During the first 3 days in hospital her fever climbed steadily each day reaching $40^{\circ} \mathrm{C}$ on the $3^{\text {rt }}$ day. Her dengue blot test was positive for $\operatorname{IgM}$ and $\lg G$ indicating a secondary dengue infection. Although clinically and laboratory evidence for acute dengue fever was established, the step ladder increase pattern of her daily temperatures after the continous 5 day fever at home (that could be attributed to dengue virus), made the possibility of a simultaneous Salmonella typhi infection most likely. The patient was given an IV course of fleroxacin $400 \mathrm{mg}$ daily and fever subsided within 3 days, discharge followed 2 days later. Her blood culture yielded Salmonella typhi sensitive to fluoroquinolones explaining the rapid response to treatment. Fluoroquinolones were favoured since they have no suppressive effect on the bone marrow, vital for the hematopoetic recovery after dengue infection. There was no severe disease interaction or prolongation of discharge from the hospital in this case of dual infection. By using the right kind of intervention properly excellent treatment results may be expected.
\end{abstract}

